\title{
International trade and domestic competition: evidence from Belgium
}

\author{
Maria Caterina Bramati* \\ Sapienza University of Rome
}

\author{
Alberto A. Gaggero ${ }^{\dagger}$ \\ University of Pavia
}

Edna Solomon $\ddagger$

University of Greenwich

February 16, 2015

\begin{abstract}
We investigate the effect of domestic market competition on firmlevel export intensity. We employ a comprehensive dataset of Belgian firms from 2005-2008, when the fall in the number of firms engaged in trade was accompanied by a growing amount of transactions. The resulting increase in the domestic concentration of Belgian firms has sparked numerous debates, since the direction of causality between domestic market structure and export performance is unclear. We apply the fractional logit estimator and control for both self selection and simultaneity bias. We find that a positive linkage exists between the level of competition and export intensity.
\end{abstract}

JEL Classification: C23, F14, L16, L40.

Keywords: Competition, Domestic Rivalry, Exports, National Champion.

* Sapienza University of Rome, Department of Methods and Models for the Economy, Territory and Finance, Via del Castro Laurenziano 9, 00161 Rome, Italy. Tel: +39 06 49766428, Fax: +39 06 4957606. Email: mariacaterina.bramati@uniroma1.it.

${ }^{\dagger}$ Department of Economics and Management, University of Pavia, Via S. Felice 5, 27100 Pavia, Italy. Tel: +39 0382 986226, Fax: +39 0382986228 . Email: alberto.gaggero@unipv.it.

${ }^{\ddagger}$ Department of International Business and Economics, University of Greenwich, Greenwich Campus, 30 Park Row, London, Greenwich, SE10 9LS, United Kingdom. Tel: +44 (0)20 83319129. Email: e.m.solomon@greenwich.ac.uk. 


\section{Introduction}

The export performance of firms and of countries is an important factor that affects economic prosperity. Firm performance along the trade dimension depends on the ability of firms to compete abroad. The hypothesis formulated by Porter (1990) advances that the degree of competition in domestic markets is positively related to performance in international markets. Some empirical results support this hypothesis (Donghwan and Marion, 1997; Sakakibara and Porter, 2001; Zhao and Zou, 2002); however, scant investigation has been devoted to the relationship between industrial concentration and export behavior.

Two hypotheses are considered in explaining the relationship between exports and competition: the national champion hypothesis, and the domestic rivalry relationship (Clougherty and Zhang, 2009). According to the national champion hypothesis, a fall in domestic competition increases the export intensity of large firms because it enables them to exploit economies of scope.

On the other hand, according to the domestic rivalry hypothesis, a rise in the level of domestic competition puts pressure on the domestic firms to innovate and to increase their productivity and efficiency levels. This enables the firms to increase their export levels.

Hence, the national champion hypothesis predicts a negative relationship between the level of domestic competition and export intensity, whereas the domestic rivalry hypothesis predicts a positive relationship. In this paper, we test which of these two hypotheses dominates in the Belgian economy with the use of a comprehensive dataset of firms that are observed between 2005 and 2008.

Our paper complements the related literature on export determinants in a number of ways: First, we examine the effect of domestic competition and export intensity with the use of a unique panel dataset from Belgium. Second, we investigate whether the size of the firm affects the relationship between domestic competition and export intensity. Third, we expand our analysis to firms outside the manufacturing sector. Finally, we employ the use of methods that are more robust to endogeneity that arise from simultaneity bias as well as from sample selection bias.

Our results show that a higher level of domestic competition leads to higher levels of exports. Thus, our results support the existence of the domestic rivalry hypothesis over the national champion hypothesis. This rela- 
tionship holds for both small and large firms.

The rest of the paper is structured as follows: the next section reviews the literature. Section 3 is devoted to the empirical analysis: first presenting the econometric model, then discussing the estimation issues, followed by the results. Finally Section 4 summarizes and concludes.

\section{Literature review}

The determinants of firm exports have been studied widely in both the economics and management literature. In the economics literature, Wagner (2001) studies the relationship between firm size and export intensity. $\mathrm{He}$ uses a fractional response model and applies the quasi-likelihood estimation method proposed by Papke and Wooldridge (1996) to a dataset of German manufacturing establishments. He finds an inverted U-shaped relationship between firm size and exports.

Wagner (2003) also examines the relationship between firm size and exports. He finds that a positive relationship exists, but the effect of firm size on exports vanishes when fixed effects are controlled for. For Wagner, the evidence suggests that several small firms are "hidden export champions".

Within the context of exporting decisions, Roberts and Tybout (1997) highlight the importance of sunk costs, which represent the direct monetary costs of entry and exit into the market. The authors develop a dynamic discrete choice model of exporting behavior that separates the role of profit heterogeneity and sunk entry costs in explaining plants' exporting status. Using a panel of Colombian manufacturing plants, they find that sunk costs are not zero and therefore the prior export-market experience significantly affects the current decision to export.

Bernard and Jensen (1999) analyze the interaction between exports and firm performance. They find that 'good' firms become exporters; however exporters do not dominate non-exporters in every aspect: That is, although survivability and employment growth are higher for exporters, productivity, and wage growth are not superior, particularly over longer horizons.

Bernard and Jensen (2004) examine the factors that increase the probability of exporting; using a panel of U.S. manufacturing plants, they find that entry costs and firm heterogeneity are the main factors that explain export propensity.

Melitz (2003) considers a dynamic industry model that incorporates firm 
productivity heterogeneity into the Krugman (1979) monopolistic competition framework. He shows that only more productive firms can enter the export market, whilst inefficient firms are bound to exit. He also finds that an industry's continuous exposure to trade leads to additional inter-firm allocation towards more efficient firms, with positive welfare gains.

Costantini and Melitz (2008) study how entry, exit, export, and innovation decisions of heterogeneous firms adjust to different trade liberalization scenarios (anticipated, gradual, and sudden). They find that the expectations of a gradual liberalization spur firms to innovate before their entry into the export market.

On the management literature side, Majocchi et al. (2005) test the effect of firm size and business experience on export performance with the use of a sample of Italian manufacturing firms observed from 1997 to 2001. They find empirical evidence in favor of positive effects of both size and experience on exports.

A comprehensive study of the relationship between firm size and export performance is conducted by Moen (1999) with the use of Norwegian firm level data. Large firms are expected to be more successful than small firms to compete in international markets because the former hold more resources and/or are able to achieve economies of scale that enhance their competitiveness (Aaby and Slater, 1999). However, Moen (1999) finds that firm size is unrelated to export performance. Small and large firms alike are successful in international markets since it is only the most competitive small firms that export.

In the fields of behavioral economics and marketing, Obadia and Vida (2011) address the influence of the importer role in the export performance of firms with the use of a structural equations that model two samples of French and Slovene firms. They find that the importer role is relevant in explaining export performance as a mediator of the impact of relational factors on export performance. Other authors suggest a transaction cost analysis to explain the effect of size on exports (Verwaal and Donkers, 2002). ${ }^{1}$

Clougherty and Zhang (2009) develop a theoretical framework to examine the relationship between domestic competition and exports. Their model shows that if the national champion effect is in operation, then a reduction in domestic market share (i.e., an increase in competition) would reduce the

\footnotetext{
${ }^{1}$ For an extensive survey in the fields of international economics and management, see Sousa et al. (2008) and Leonidou et al. (2010).
} 
export share due to joint economies of production (or economies of scope) across domestic and foreign markets. The national champion effect more usually occurs for large firms.

On the other hand, an increase in competition would have the opposite effect - an increase in export share - if the domestic rivalry effect is operational. In the absence of joint economies of production, a rise in competition would put pressure on firms to innovate and engage in cost cutting operations, which would increase the competitiveness of the firms and, most likely improve their performance in the international market and hence their export share. Clougherty and Zhang (2009) test their model empirically with the use of data from the world airline industry. They find evidence of the existence of the domestic rivalry hypothesis in the world airline industry.

Some empirical works that use Belgian data are carried out by Glejser et al. (1980), Pisu (2008), and Muûls and Pisu (2009). The last of these articles examines imports and exports with the use of firm-level Belgian data from 1996 to 2006 and draws three key findings:

First, firms that engage in exporting and importing activities are concentrated among the largest and most productive firms. Second, there is a negative relationship between the number of firms that engage in international trade and the number of countries with which they trade. Finally, there is a positive relationship between the productivity of firms and the number of export destinations or import origins. This is because a fixed cost is incurred by the firm for each additional export destination or import origin.

In a related work, Pisu (2008) investigates the effects of exports on productivity across different destinations. Using a panel of Belgian manufacturing firms observed from 1998 to 2005, he finds that self selection drives the link between export and productivity. Moreover, there is positive relationship between the pre-export productivity levels of firms and the development level of export destination countries.

The research of Glejser et al. (1980) is closely related to our paper. With the use of Belgian micro-data from a field interview, they study empirically the relationship of export intensity of Belgian exporters with domestic and international market structure. Their results are in favor of the domesticrivalry effect. To conduct their analysis, they apply ordinary least squares to a log-odds ratio model specification with a dataset of 1,446 Belgian exporters.

Our work improves upon that of Glejser et al. (1980) in a number of ways: First, we make use of a more recent database from 2005-2008. Second, unlike 
Glejser et al. (1980) our sample includes firms in both the manufacturing and non-manufacturing sectors. Third, we make use of an estimator that better controls for the endogeneity and the nature of the zero-one bounded dependent variable.

\section{Empirical analysis}

\subsection{Model}

We aim to establish whether there is a link between domestic competition and export intensity with the use of a detailed panel dataset of Belgian firms from 2005 to 2008. Our sample comprises 3,932 firms and 367 sectors that are defined according to four-digit classification of the Nomenclature statistique des Activités économiques dans la Communauté Européenne (NACE) 2008 Rev. 2. ${ }^{2}$

Our model specification takes into account the two types of export decisions made by firms. The first decision is whether to export or not to export (i.e., export propensity); the second decision is how much of output to export (i.e., export intensity). Failure to account for the first decision will lead to a sample selection bias. Therefore, following Greenaway et al. (2004), we model the export propensity and the export intensity for firm $f$ in industry $i$ at time $t$ using the following equations:

$$
\begin{aligned}
\text { Exp_Propensity }_{f i t}= & \alpha_{0}+\alpha_{3} \log \left(\text { Age }_{f i t}\right)+\alpha_{3} \log \left(\text { Size }_{f i t}\right)+ \\
& +\alpha_{3}{\text { Fraction_Exporter } s_{i t}+\varepsilon_{f i t},}
\end{aligned}
$$

and

$$
\begin{aligned}
\text { Exp_Intensity }_{\text {it }}= & \beta_{0}+\beta_{1} \log \left(\text { Size }_{\text {fit }}\right)+\beta_{2} \log \left(\text { Salary }_{f i t}\right)+ \\
& +\beta_{3} H H I_{i t}+\beta_{4} \text { Import_Share }_{i t}+u_{f i t},
\end{aligned}
$$

where $\varepsilon_{i f t}$ and $u_{i f t}$ are the random error terms, which are assumed to be normally distributed and possibly correlated. The definition of all variables including instruments (see Appendix A2) is given in Table 1, whilst Table 2 reports the summary statistics.

Equation 1 is estimated for the full sample of firms. The dependent variable (Exp_Propensity) is a dummy variable that takes the value of 1 if the

\footnotetext{
${ }^{2}$ Data sources are described in the Appendix.
} 
Table 1: Variable definition

\begin{tabular}{ll}
\hline Variable & Description \\
\hline \hline Exp_Propensity & $\begin{array}{l}\text { dichotomous variable that takes the value 1 if the firm } \\
\text { exports and 0 otherwise. } \\
\text { Exp_Intensity } \\
\text { export intensity of the firm, which is calculated as the } \\
\text { ratio of exports/turnover. }\end{array}$ \\
Age & Number of years since the firm entered the VAT register. \\
Size & Number of the firm's full-time equivalent employees. \\
Fraction_Exporters & Fraction of exporting firms divided by all of the firms \\
in the industry. & Average annual salary (in Euros) in each firm, \\
Salary & deflated (base year 2005). \\
HHI & Herfindahl index defined at the four-digit NACE level. \\
Import_Share & Import share of domestic sales for the industry. \\
Heckman's lambda & Inverse Mills ratio obtained from equation (1). \\
White Collar Employment \% & $\begin{array}{l}\text { Percentage of the firm's total employment that are white } \\
\text { collar employees. }\end{array}$ \\
Industry_Growth & Average annual percentage growth of the industry. \\
\hline
\end{tabular}

Table 2: Summary statistics

\begin{tabular}{lcccccc}
\hline Variable & Mean & $\begin{array}{c}\text { Standard } \\
\text { deviation }\end{array}$ & $\begin{array}{c}\text { Min } \\
\text { value }\end{array}$ & $\begin{array}{c}\text { Max } \\
\text { value }\end{array}$ & $\begin{array}{c}\text { Between-firm } \\
\text { variation }\end{array}$ & $\begin{array}{c}\text { Within-firn } \\
\text { variation }\end{array}$ \\
\hline \hline Exp_Propensity & 0.78 & 0.41 & 0.00 & 1.00 & 0.41 & 0.17 \\
Exp_Intensity & 0.28 & 0.31 & 0.00 & 1.00 & 0.31 & 0.04 \\
Age & 22.67 & 10.18 & 1.00 & 38.00 & 10.37 & 0.86 \\
Size & 56.04 & 195.69 & 1.00 & 10,933 & 137.14 & 143.72 \\
Fraction_Exporters & 0.58 & 0.23 & 0.00 & 1.00 & 0.23 & 0.07 \\
Salary & 24,528 & 7,839 & 959 & 111,109 & 6,618 & 5,087 \\
HHI & 0.31 & 0.25 & 0.00 & 1.00 & 0.25 & 0.04 \\
Import_Share & 0.01 & 0.03 & 0.00 & 0.33 & 0.23 & 0.02 \\
White Collar Employment \% & 0.55 & 0.34 & 0.00 & 1.00 & 0.29 & 0.21 \\
Industry_Growth & -0.02 & 0.43 & -18.30 & 0.96 & 0.34 & 0.34 \\
\hline
\end{tabular}


firm exports or 0 if it does not. We include three key determinants of export propensity: Firm age (Age) and size (Size) capture the fact that larger, more experienced firms have a higher probability of exporting. ${ }^{3}$ This is because of the fixed costs involved in exporting. The fraction of exporting firms in the sector (Fraction_Exporters) proxies for agglomeration or spillover effects that arise from other exporters in the same industry of the firm. These effects are likely to have a positive influence on the decision to export (Greenaway and Kneller, 2007).

For equation 2, the dependent variable measures the export intensity of the firms (Exp_Intensity). We include several explanatory variables of export intensity. Firm size (Size) controls for any effects that the dimension of the firm may have on export intensity. Real wages (Salary) is a broad proxy for the skill level of workers in the firm (Wagner, 2011). This is because, on average, more highly skilled workers are expected to receive higher wages. Therefore, greater values of the average wage could indicate a higher qualification of the work force, which, all else being equal, should have a positive impact on exports. ${ }^{4}$

Our key variable is the Herfindahl Hirschman index $(H H I)$, which represents (the inverse of) the domestic competition. For each industry, $H H I$ is computed as the sum of the firms' squared market shares, defined as follows:

$$
x_{f i t}=\frac{T_{f i t}}{\sum_{f=1}^{n} T_{f i t}+M_{i t}}
$$

where $x_{f i t}$ is the market share of firm $f$ operating in industry $i$ at time $t$. It is calculated as the fraction of firm $f$ 's turnover $T_{f i t}$ at time $t$ over the sum of the turnovers of all $f=1, \ldots n$ domestic firms plus the total imports $M_{i t}$ from foreign firms in industry. ${ }^{5}$

However, in some sectors, such as the construction, retail, hospitality, beverage, and food processing industries, the relevant market might be local

\footnotetext{
${ }^{3}$ Age is computed as the time elapsed between the current year minus the year of firm entry into the VAT register (which was introduced in 1971). The firms that were in existence before the start of the VAT in Belgium are given the birth year of 1970.

${ }^{4}$ Salary is deflated using the Belgian consumer price index, from the World Development Indicators of the World Bank.

${ }^{5}$ Our measure of market share is inclusive of imports as they affect the overall competitiveness of the domestic market. We assume that the imports are coming from a set of atomistic firms.
} 
- typically at the municipality level - rather than national. Thus for those sectors $H H I$ is computed as the weighted average of the Herfindahl indexes defined at the municipality level. In formula:

$$
H H I_{i t}=\sum_{m=1}^{k} w_{m i t} h_{m i t} ; \quad h_{m i t}=\sum_{f=1}^{p} x_{f m i t}^{2}
$$

where the weights $w_{\text {mit }}$ are given by the proportion of the total number of firms located in municipality $m$ and operating in sector $i$, relative to the total number of all of the firms of sector $i$ that are registered in the country. The total number of municipalities in which we observe at least one firm of sector $i$ is given by $k{ }^{6}$

To examine whether competition from imports has a distinct effect on exports, we include the import share of domestic sales at the four-digit level NACE as an additional regressor (Import_Share). Again, for those industries that are characterized by local competition, import share at the sectoral level is obtained as a weighted average of the import shares at the municipality level, using the same weights that are used in the computation of the Herfindahl index above.

We do not explicitly control for comparative advantage in our model. However, in line with Greenaway and Kneller (2007) and Wagner (2011), we expect Belgian firms to move human capital and technology towards industries and products in which they enjoy comparative advantage. Such an allocation of resources would enable firms to increase their success in exporting and avoid direct competition from countries in industries where they have a comparative disadvantage.

\subsection{Estimation techniques}

The empirical techniques that we apply are selected to tackle three important methodological issues:

First, since by construction the export intensity of a firm is a continuous variable that ranges between zero and one, equation (2) depicts a fractional

\footnotetext{
${ }^{6}$ The Herfindahl index at the municipality level $h_{m i t}$ is calculated with the same approach that is illustrated in equation (3): the only difference is that now the relevant market is the municipality rather than the country as a whole. Thus the market shares $x_{f m i t}$ used to calculate $h_{m i t}$ are computed at the municipality level. If there are $p$ firms of industry $i$ in municipality $m$, then $x_{f m i t}=\frac{T_{f m i t}}{\sum_{f=1}^{p} T_{f m i t}+M_{m i t}}$.
} 
response model. In such models, the standard linear regression approach is not appropriate because the effect of any particular regressor cannot be constant throughout its domain, unless the range of the regressor is very limited. For this reason we estimate equation (2) using the fractional logit estimator of Papke and Wooldridge (1996).

This approach is a pooled methodology, which, in this particular context, is preferred to the fixed-effect methodology that is illustrated in Papke and Wooldridge (2008). As discussed by Wagner (2011), although the fixedeffect approach allows for the control of unobserved characteristics of the firm that might be correlated with the observed characteristics, it hinges on the within-firm variability of the regressors and thus may imprecisely estimate the coefficient of an independent variable that is characterized by little within-firm variation over time. As Table 2 shows, this is precisely the case for our variable of interest, the Herfindahl index.

The second important issue that needs to be addressed is endogeneity. Endogeneity could potential arise from two sources. One source is from the endogenous sample selection bias that arises from firms that self select into exports. For this reason, we apply the Heckman Selection Model (HSM) to equation (1) so as to obtain the inverse of the Mills' ratio (Heckman 1979). This is included as an additional regressor in the fractional logit estimation to adjust for sample selection bias in the export intensity model. ${ }^{7}$

The other source of endogeneity arises from possible reverse causation of the regressors in equation (2). Export activity increases the average level of industrial output and profits, because it leads to the exit of inefficient firms, and the expansion of the more productive firms (Greenaway and Kneller, 2007). Sectoral levels of output and profits could plausibly have an effect on the level of the Herfindahl index (by construction), as well the employment and wage decisions of firms.

For this reason, we treat the Herfindahl index $(H H I)$, numbers of workers (Size), and mean paycheck of employees (Salary) as endogenous. We adopt a two-stage approach in dealing with potential endogeneity. First, we regress each endogenous regressor on an instrument and other exogenous variables

\footnotetext{
${ }^{7}$ An alternative approach to our two-step method would be to use a Tobit model. However, this model does not fully account for the reasons why some observations are latent, but it simply corrects for them. With our approach, instead, we first model the factors that increase the chances of firms' self-selecting into exporting and then we correct for the self-selection bias including these drivers (through the inverse Mills ratio) as an input in the export intensity equation.
} 
from equation (2). Then the fitted values of each endogenous regressor that are obtained from the 'first-stage estimation' are used as regressors in the fractional logit estimation. ${ }^{8}$

Finally, the third important issue deals with the fact that companies that operate in the same industry during the same year could be subject to the same shock. Consider, for instance, a change in consumers' preferences (e.g., people switching from a Belgian beer to a German one), or the imposition of new quotas and tariffs: In such cases the export performance of all firms in the sector is likely to be affected and thus the residuals in equations (1) and (2) may be correlated. In order to control for such residuals' correlation, we cluster the standard errors of both equations by sector and year.

\section{$3.3 \quad$ Results}

Table 3 presents the results from the HSM estimations. The age (Age) and size (Size) of the firm have positive and a highly statistically significant effects on the probability of firms to export. These results are in line with the literature. There is a fixed cost to exporting (Greenaway and Kneller, 2007). Hence, larger, more experienced firms are more likely to engage in exporting activities (Majocchi et al. 2005). Also, spillover effects from exporters in the same industry (Fraction_Exporters) have a statistically significant effect on the propensity of the firm to export.

When we turn to the fractional logit estimations, column 1 of Table 4 presents the results for the full sample of firms. According to Clougherty and Zhang (2009), the national champion hypothesis is more dominant in larger firms, since such firms are more likely to benefit from economies of scope. Hence, in columns (2) and (3) of Table 4, we split our sample into small and large firms respectively. ${ }^{9}$

We conduct the Chow test to check whether two different regression models should be estimated for small firms and large firms. The diagnostic reports a $\chi^{2}$ equal to 57.64 . This value is statistically significant at the $1 \%$ level, which indicates that regression coefficients estimated in the two regressions

\footnotetext{
${ }^{8}$ The first-stage estimates with a brief description of the instruments are reported in the Appendix.

${ }^{9}$ We follow the classification that has been adopted by the European Commission (2003), which categorizes companies with fewer than 50 employees as "small", whilst those above as "medium-large".
} 
Table 3: Export decision

\begin{tabular}{lc}
\hline & $(1)$ \\
\hline \hline $\log ($ Age $)$ & $0.069^{* * *}$ \\
& $(0.022)$ \\
$\log ($ Size $)$ & $0.050^{* * *}$ \\
& $(0.008)$ \\
Fraction_Exporters & $2.328^{* * *}$
\end{tabular}

Observations $\frac{15,246}{\text { (a) Probit estimation. Dependent variable Exp_Propensity. }}$
(b) Coefficients statistically significant at the $1 \%, 5 \%$, and $10 \%$ level are denoted,
respectively, by ***, $* *$, and *.
(c) Robust standard errors to heteroscedasticity and serial correlation are in parenthesis,
clustered by sector-year.
(d) Time dummy variables for years 2006,2007 , and 2008 are included, but not reported.

are different and therefore the sample should be split into small firms and large firms.

In the small-firm and large-firm regressions, Size is not a significant factor in explaining export intensity among our sample of firms. Taken together with Table 3, our results show that the size of the firm is a relevant factor that enables firms to meet the sunk costs of exporting. However, once firms become exporters, its importance in explaining export intensity is not significant .

We also find that average wages (Salary) is not a statistically significant factor that explains export intensity for small firms. For large firms, however, the relationship is negative and significant. This result may indicate that greater human capital (which is proxied by Salary) for large firms is more valuable for domestic sales than for exports.

The coefficient on our key variable of interest $(H H I)$ is negative and statistically significant at the $1 \%$ level. This result supports the domestic rivalry hypothesis, since fiercer home competition forces firms to become more efficient and spurs them to expand their markets abroad. This result is in line with the hypothesis on the negative effect of market concentration in export performance that is illustrated by Porter (1990).

The effect of competition on export intensity is qualitatively similar for 
both small and large firms alike. This gives us confidence that the domestic rivalry hypothesis does in fact prevail in Belgium. Our results are in line with Glejser et al. (1980), who find evidence in favor of domestic rivalry in Belgium with a different estimation technique and a different sample period.

Table 4: The effect of competition on export intensity.

\begin{tabular}{lccc}
\hline & $\begin{array}{c}(1) \\
\text { Full sample }\end{array}$ & $\begin{array}{c}(2) \\
\text { Small firms }\end{array}$ & $\begin{array}{c}(3) \\
\text { Large firms }\end{array}$ \\
\hline \hline$\widehat{\log (\text { Size })}$ & 0.029 & -0.003 & 0.085 \\
& $(0.041)$ & $(0.044)$ & $(0.059)$ \\
$\log \widehat{(\text { Salary })}$ & -0.271 & -0.014 & $-0.796^{* * *}$ \\
& $(0.172)$ & $(0.177)$ & $(0.303)$ \\
$\widehat{H H I}$ & $-1.421^{* * *}$ & $-1.294^{* * *}$ & $-1.655^{* * *}$ \\
& $(0.147)$ & $(0.152)$ & $(0.173)$ \\
Import_Share & $0.203^{* *}$ & $0.205^{* * *}$ & 0.225 \\
& $(0.090)$ & $(0.075)$ & $(0.171)$ \\
Heckman's lambda & $3.594^{* * *}$ & $4.343^{* * *}$ & $7.060^{* * *}$ \\
& $(0.509)$ & $(0.573)$ & $(1.224)$ \\
Chow $\chi^{2}$ & & & \\
Observations & $57.64^{* * *}$ & & 2,103 \\
\hline
\end{tabular}

(a) Fractional logit estimation. Dependent variable Exp_Intensity.

(b) Coefficients statistically significant at the $1 \%, 5 \%$, and $10 \%$ level are denoted, respectively, by $* * *, * *$, and *.

(c) Robust standard errors to heteroscedasticity and serial correlation are in parenthesis, clustered by sector-year.

(d) A firm is classified as "large" if employs more than 50 employees, and "small" otherwise (European Commission, 2003).

(e) Time dummy variables for years 2006, 2007, and 2008 are included, but not reported.

The results also show that a higher import share (Import_Share) in the sector has a positive and statistically significant effect on export intensity for small firms. This finding shows evidence of complementarity between import penetration and export activities for small firms.

Finally, the inverse mills ratio (Heckman's lambda) is highly statistically significant in all three columns. Hence, a lack of correction for firms that self-select into exporting would lead to a sample selection bias in the export intensity regressions. 
The main exporting sectors in Belgium are the manufacturing and service industries. In 2008, these sectors accounted for about $68 \%$ and $13 \%$ of total exports respectively (OECD, 2014). The main exports from these sectors include: vehicles, metallurgic products, metallic products, non metallic minerals, ICT services, and business services. On the other hand, utilities and construction are the lowest exporting sectors, with each accounting for less than $1 \%$ of total exports in 2008 (OECD, 2014).

Since we believe that industrial heterogeneity in terms of technology, innovation, and productivity could play a relevant role in the effect of domestic competition on exports, we investigate this relationship also at the sectoral level. To conduct the analysis we consider six NACE macro-groups: construction, manufacturing, services, retail \& wholesale, transport, and utilities. We estimate equation (2) for each of these six sub-samples (see Table 5).

The Chow test yields a $\chi^{2}$ value of 406.68 , which is significant at the $1 \%$ level. This shows that the estimated coefficients on the sub-sectors are significantly different from the estimates of the entire sample, which suggests the need to split the sample into sub-sectors.

The sign of the coefficient on the Herfindahl index, our variable of interest, is consistent with that obtained in Table 4, except in the Construction sector, where the coefficient is positive but insignificant. However, it is only in the Manufacturing and Retail/Wholesale sectors where our measure of competition has statistically significant effects on export intensity.

This result is confirmed when the sample is split into small and large firms (see Tables 6 and 7, respectively). Again, the negative relationship between the degree of concentration of industries and export intensity is found to be highly significant in both the Manufacturing and Retail/Wholesale sectors.

Contrary to the main results, for small firms in the Transport industry, the effect of market concentration on exports is positive, but not significant. However, coefficient estimates that are related to some sectors, such as Transport, should be treated with caution because the number of observations in the transport sector is very small, thus the reliability of the result is undermined by a reduction in the degrees of freedom. 


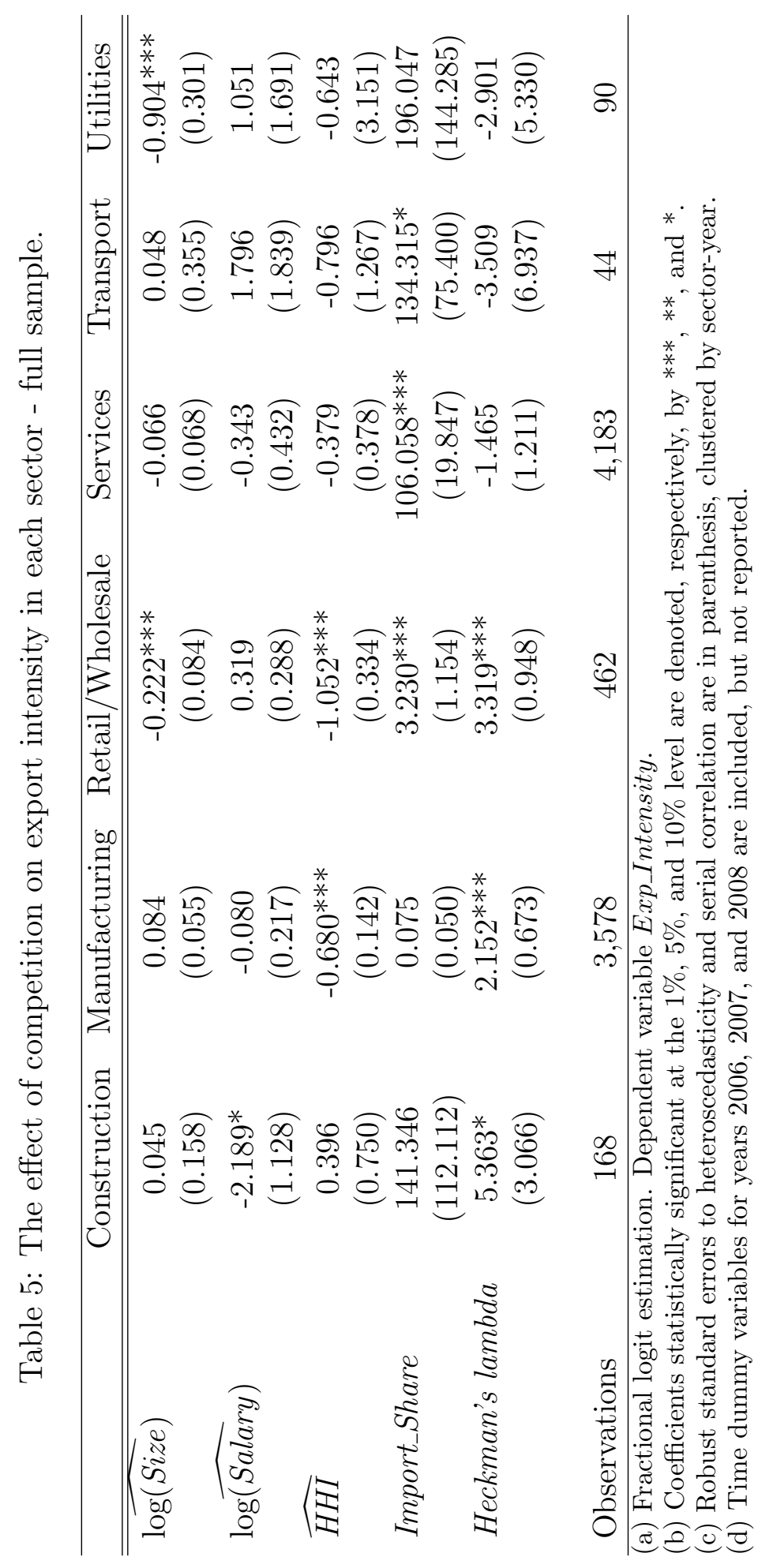




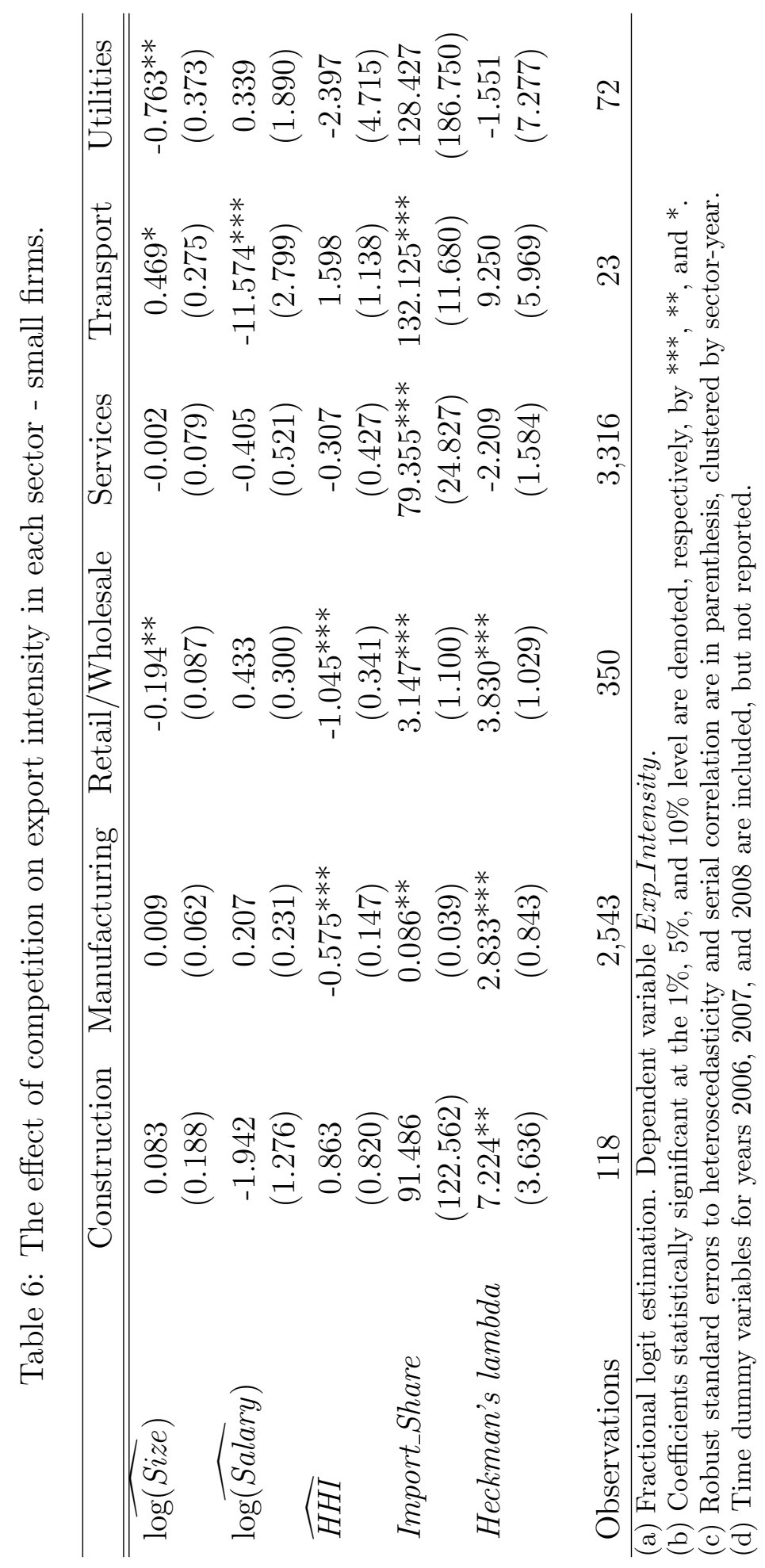




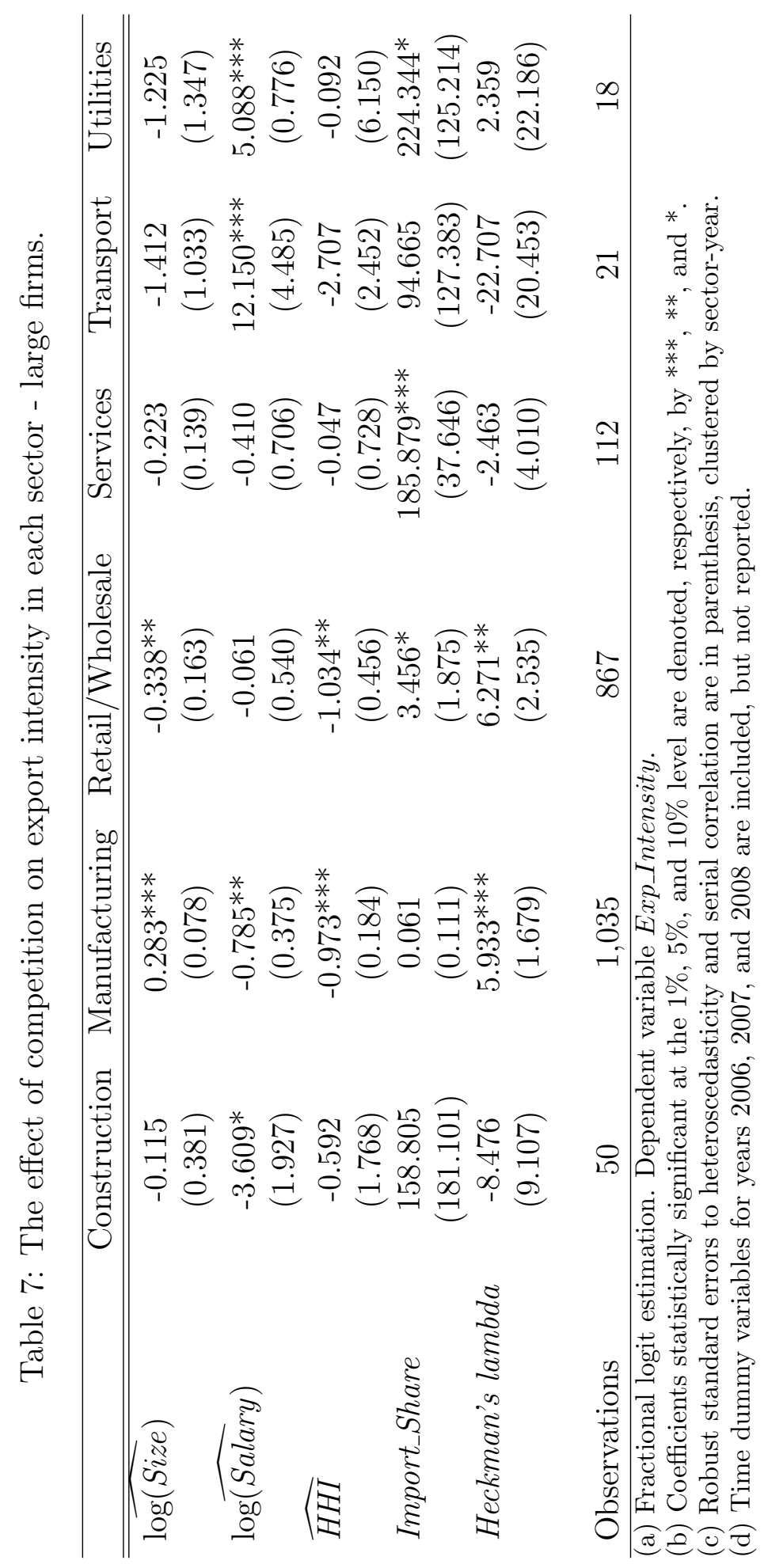




\section{Conclusions}

In this paper we have investigated the effect of domestic competition on firmlevel export performance. As explained in Clougherty and Zhang (2009), this effect can either be negative or positive and thus respectively supports the national champion hypothesis or the domestic rivalry hypothesis.

The domestic rivalry hypothesis points to a positive link between domestic competition and export performance, as fierce competition in highly saturated markets will spur domestic firms to innovate and this will allow firms to gain larger export market shares.

The national champion hypothesis maintains that a lower degree of competition in the domestic market can guarantee a stable position for the incumbents that will be able to exploit economies of scope by seeking further expansion abroad. The national champion hypothesis is more likely to hold in domestic markets dominated by large firms.

We tested which of the two hypotheses dominates in the Belgian economy by applying the fractional logit estimation technique of Papke and Wooldridge (1996) to a comprehensive dataset of 3,932 Belgian firms that are observed during the period 2005-2008.

Our methodology ensured that we controlled for the endogeneity that arises from firms' self-selecting into export activities and the endogeneity that arises from the simultaneity of certain regressors.

We found that the domestic rivalry hypothesis holds in the Belgian economy, especially in the Manufacturing and Retail/Wholesale sectors. This result is largely consistent by sector and for both small and large firms. Since exports are a very important contributor to the Belgian economy, our results support pro-competition policies as a tool to increase export activity in Belgium.

Acknowledgments. We are deeply grateful to the editor, Prof. Lawrence J. White, and the two anonymous referees whose very helpful comments have greatly contributed to the paper. We also wish to thank Antonio Majocchi, Edward Norton, João Santos Silva, Joachim Wagner, Jeffrey Wooldridge, and the participants of the 2010 Conference in honor of Giancarlo Gandolfo for their suggestions. All remaining errors are ours. 


\section{Appendix}

\section{A1 Data sources}

Our empirical investigation employs firm-level data for 3,932 Belgian companies that are observed during the period 2005-2008. The dataset covers all of the industries of the Belgian economy, with the exception of agriculture and fisheries. The classification of the economic activities of firms (NACE) that is used in the analysis is the 2008 version. Data are accessed via SPF Economie (i.e., the Belgian Federal Ministry of Economy).

Our firm-level data are constructed as follows: we merge data from four Belgian administrative sources:

The first source is the collection of records of the universe of firms that are subject to the tax system (VAT register).

The second source is the collection of the operating statements of firms for which such declaration is compulsory. The variables included are on employment, industry affiliation, profits, and total sales together with the firm identifier (KBO number).

Third, Belgian Customs compile all sales of Belgian firms across all nonEuropean foreign destinations which, combined with the Intrastat survey on foreign trade for European trading partners, can be matched with the other two administrative databases by the firm identifier.

Fourth, data from the National Security Service (ONSS) on employment (labor costs and number of employees/workers in full-time equivalent) are added to our sample by mean of the VAT identifier. Data on the number of full-time equivalent workers and on labor costs are quarterly and have been aggregated to yearly values, summing costs and averaging the workforce.

Trade data on individual transactions concerning exports or imports are collected separately at the company level for intra-EU (Intrastat) and extraEU (Extrastat) trade. Different types of international trade transactions are reported. Companies report Intrastat transactions monthly. These are only liable for Intrastat declarations if their annual trade flows (receipts or shipments) exceed the threshold of $250,000 €$.

There are two kinds of declaration: the standard one, and the extended one. Both declarations must include for each transaction the product code, the type of transaction, and the destination or origin of the goods, the value, the net mass, and units. Companies that exceed the threshold of 25,000,000€ for their annual receipts or shipments must fill out the extended declaration. 
In addition to the same common variables of the standard declaration, the means of transport and the conditions of delivery must be included in the extended declaration.

Extrastat contains exactly the same information as Intrastat for transaction flows with countries outside the European Union. The data is collected by customs agents and centralized at the National Bank of Belgium. The Extrastat data cover a larger share of the total trade transactions than do the Intrastat data, because all flows are recorded, unless their value is smaller than $1,000 €$ or their weight is smaller than one ton.

\section{A2 First stage estimates}

Table 8 reports the first-stage estimates for $\log ($ Size $), \log$ (Salary), and HHI. These variables are instrumented as follows.

The size of the firm is instrumented with the log of the number of years of activity since the beginning of the firm (or since 1971): $\log ($ Age). The positive sign that is found on $\log ($ Age) in column (1) indicates that older firms are also larger firms in terms of employed people.

The average salary is instrumented with the percentage of white collar employees divided by the total number of employees (White Collar Employment \% ) ; thus we expect, and indeed we find, a positive correlation between the proportion of white collar employees and the average salary.

The Herfindahl Index is instrumented with the average yearly growth of the industry in percentage terms (Industry_Growth). The idea is that the higher is the growth rate in an industry, the higher is the likelihood of entry by new firms; this leads to a greater extent of competition in the industry, which translates to lower values of $H H I$. 
Table 8: First-stage results - OLS estimation.

\begin{tabular}{lccc}
\hline & $(1)$ & $(2)$ & $(3)$ \\
Dependent Variable & $\log (\operatorname{Size})$ & $\log ($ Salary $)$ & $H H I$ \\
\hline \hline $\log ($ Age $)$ & $0.440^{* * *}$ & & \\
& $(0.031)$ & & \\
White Collar Employment $\%$ & & $0.285^{* * *}$ & \\
& & $(0.012)$ & \\
Industry_Growth & & & $-0.007^{* *}$ \\
& & & $(0.003)$ \\
Import_Share & -0.040 & -0.000 & -0.004 \\
& $(0.027)$ & $(0.006)$ & $(0.007)$ \\
Year 2006 & $0.548^{* * *}$ & $0.028^{* * *}$ & $-0.013^{* * *}$ \\
& $(0.065)$ & $(0.005)$ & $(0.003)$ \\
Year 2007 & $0.652^{* * *}$ & $0.045^{* * *}$ & $-0.015^{* * *}$ \\
& $(0.070)$ & $(0.005)$ & $(0.004)$ \\
Year 2008 & $0.689^{* * *}$ & $0.079^{* * *}$ & 0.005 \\
& $(0.082)$ & $(0.006)$ & $(0.004)$ \\
Heckman's lambda & $-7.072^{* * *}$ & $-0.529^{* * *}$ & $0.029^{* *}$ \\
& $(0.401)$ & $(0.044)$ & $(0.014)$ \\
& & & \\
Observations & 13,117 & 13,117 & 13,117 \\
\hline
\end{tabular}

(a) Coefficients statistically significant at the $1 \%, 5 \%$, and $10 \%$ level are denoted, respectively, by $* * *, * *$, and *.

(b) Robust standard errors to heteroscedasticity and serial correlation are in parenthesis, clustered by sector-year.

(c) The regressions include industry fixed effects. Year 2006, Year 200\%, and Year 2008 are year dummy variables. 


\section{References}

Aaby, N., \& Slater, S. (1989). Management influence on export performance: a review of the empirical literature. International Marketing Review, 6(4), $7-26$.

Bernard, A., \& Jensen, B. (1999). Exceptional exporter performance: cause, effect, or both?. Journal of International Economics, 47(1), 1-25.

Bernard, A., \& Jensen, B. (2004). .Why Some Firms Export. The Review of Economics and Statistics, 86(2), 561-569.

Clougherty, J., \& Zhang, A. (2009). Domestic rivalry and export performance: theory and evidence from international airline markets. Canadian Journal of Economics, 42(2), 440-468.

Costantini, J., \& Melitz, M. (2008). Dynamics of Firm-Level Adjustment to Trade. In: The Organization of Firms in a Global Economy, Helpman E., D. Marin and T. Verdier, Cambridge Harvard University Press, 2008.

Donghwan, K., \& Marion, B. (1997). Domestic Market Structure and Performance in Global Markets: Theory and Empirical Evidence from U.S. Food Manufacturing Industries. Review of Industrial Organization, 12(3), $335-354$.

European Commission (2003). EU recommendation 2003/361. Retreived June 10, 2013, from http://eurlex.europa.eu/LexUriServ/LexUriServ.do?uri=OJ:L:2003:124:0036:0041:EN:PDF.

Glejser, H., Jacquemin, A., \& Petit, J. (1980). Exports in an Imperfect Competition Framework: An Analysis of 1,446 Exporters. Quarterly Journal of Economics, 94, 507-524.

Greenaway, D., \& Kneller, R. (2007). Firm heterogeneity, exporting and foreign direct investment. Economic Journal, 117(517), 134-161.

Greenaway, D., Sousa, N., \& Wakelin, K. (2004). Do domestic firms learn to export from multinationals?. European Journal of Political Economy, 20(4), 1027-1043.

Heckman, J. (1979). Sample selection bias as a specification error. Econometrica, 47 (1), 153-61. 
Krugman, P. (1979). Increasing returns, monopolistic competition, and international trade. Journal of International Economics, 9(4), 469-479.

Leonidou L., Katsikeas, C., \& Coudounaris, D. (2010). Five decades of business research into exporting: a bibliographic analysis. Journal of International Management, 16(1), 78-91.

Majocchi A., Bacchiocchi, E., \& Mayrhofer, U. (2005). Firm size, business experience and export intensity in SMEs: a longitudinal approach to complex relationships. International Business Review, 14(6), 719-738.

Melitz, M. (2003). The impact of trade on intra-industry reallocations and aggregate industry productivity. Econometrica, 71(6), 1695-1725.

Moen, O. (1999). The relationship between firm size, competitive advantages and export performance revisited. International Small Business, 18(1), 53-72.

Muûls, M., \& Pisu, M. (2009). Imports and Exports at the Level of the Firm: Evidence from Belgium. The World Economy, 32(5), 692-734.

Obadia, C., \& Vida, I. (2011). Cross-border relationships and performance: Revisiting a complex linkage. Journal of Business Research, 64(5), 467-475.

OECD (2014). STAN Bilateral Trade Database by Industry and End-use category. Retrieved November 10, 2014, from https://stats.oecd.org/index.aspx?queryid $=32186$

Papke, L., \& Wooldridge, J. (1996). Econometric Methods for Fractional Response Variables with an Application to 401(k) Plan Participation Rates. Journal of Applied Econometrics, 11(6), 619-632.

Papke, L., \& Wooldridge, J. (2008). Panel data methods for fractional response variables with an application to test pass rates. Journal of Econometrics, 145(1-2), 121-133.

Pisu, M. (2008). Export destinations and learning-by-exporting: evidence from Belgium. National Bank of Belgium, Working Paper Research No. 140.

Porter, M. (1990). The Competitive Advantage of Nations. Harvard Business Review, 68(2), 73-93. 
Roberts, M., \& Tybout, J. (1997). The Decision to Export in Colombia: An Empirical Model of Entry with Sunk Costs. American Economic Review, 87(4), 545-64.

Sakakibara, M., \& Porter, M. (2001). Competing at Home to Win Abroad: Evidence from Japanese Industry. Review of Economics and Statistics, 83(2), 310-322.

Sousa, C., Martinez-Lopez, F., \& Coelho, F. (2008). The determinants of export performance: a review of the research in the literature between 1998 and 2005. International Journal of Management Reviews, 10(4), 343-374.

Verwaal, E., \& Donkers, B. (2002). Firm size and export intensity: Solving an empirical puzzle. Journal of International Business Studies, 33(3), 603613.

Wagner, J. (2001). A note on the firm size - export relationship. Small Business Economics, 17(6), 229-237.

Wagner, J. (2003). Unobserved firm heterogeneity and the size-exports nexus: Evidence from German panel data. Review of World Economics, 139, 161-172.

Wagner, J. (2011). Exports and Firm Characteristics in German Manufacturing Industries. Applied Economics Quarterly, 57(2), 107-143.

Zhao, H., \& Zou, S. (2002). The Impact of Industry Concentration and Firm Location on Export Propensity and Intensity: An Empirical Analysis of Chinese Manufacturing Firms. Journal of International Marketing, 10(1), $52-71$. 